\title{
Branding the City: The Democratic Legitimacy of a New Mode of Governance
}

Jasper Eshuis and Arthur Edwards

This is a concept version of the article that has been published as:

Eshuis, J. and A. Edwards (2013) Branding the City: The Democratic Legitimacy of a New Mode of Governance. Urban Studies 50 (5): 1066-1082

\section{Introduction}

Branding has become an empirical phenomenon in the governance of urban districts and communities, especially in urban regeneration programmes (e.g. Van Dijk and Holstein, 2007). Branding has been widely applied to change the image of regenerated areas, with the aim of attracting investors and new residents. In the UK for example, branding has become increasingly central to regeneration partnerships in order to "market schemes to developers, business and the public" (Jones and Evans, 2008, p 75).

According to the literature on place branding, the branding of districts or communities aims to create a favourable image of the place by emphasising certain functional, symbolic, and experiential aspects (cf. Kavaratzis, 2008). The place brand is a symbol that suggests ways of experiencing or relating to the community (cf. Arvidsson, 2006). Place branding is used as an urban governance strategy for managing perceptions about places. It includes perceptions of opportunities within a place and its identity, and it may involve ideas about economic and spatial development. Place branding may be directly coupled to urban governance, following the rationale that a place first decides what kind of brand it wants to become and then enhances developments to support that brand (Kavaratzis, 2008). In such cases, branding plays a role at both the symbolic level and the level of urban policies.

The upsurge of place branding can be linked to the emergence of "the entrepreneurial city" (Hall and Hubbard, 1998) and neo-liberal policy programmes in American and European cities (Hackworth, 2007; Greenberg, 2008). Based on a free-market ideology, these programmes propose a decrease in state regulation and the introduction of private-sector strategies. Marketing-led strategies of economic development have come to play a more important role (Greenberg, 2008).

Doubts have, however, been raised concerning the effects of branding in terms of democratic legitimacy. Although comprehensive research on the democratic legitimacy of place branding is lacking, scholars have been critical about several issues. They argue that place branding and place marketing have been applied as a form of spin that prevents the public from properly knowing what their government is doing (see Brownill, 1994; Greenberg, 2008). Kavaratzis (2008) points to the risk of governments and public-private partnerships launching place brands without consulting local communities. Analysing the case of Amsterdam, he asserts that citizens were hardly involved in selecting the main dimensions of the place brand: a consultancy selected the three main brand values. Bennett and Savani (2003) describe how public officials, in consultation with private parties, bypass elected politicians when taking 
strategic decisions around place branding. Place branding has been criticised for creating a gap between image and reality by neglecting social deprivation and poverty (see Paddison, 1993).

On the other hand, if branding is applied in the public realm, in the context of democratic political institutions, it can be argued that branding processes have democratic legitimacy; but this depends on how branding is applied in practice. Branding may give citizens influence on the symbolic representation and the aspired identity of their community if they are involved in the decision making about the brand. Critics, however, may counter this idea by questioning the value of influencing symbolic representation if one is excluded from debates about larger developments and the overall (neo-liberal) policy agenda.

In this article, we therefore pay attention to the interrelatedness between the democratic legitimacy of branding and wider urban policy developments. We investigate whether or not the branding process provides new avenues for citizens, even in the roles of clients and consumers, through which they may influence political decision making. Whether this is empirically the case is the subject of our research. The relation between place branding and democratic legitimacy, and specifically the role of citizens in branding processes, are in need of further empirical research.

Our research question is: To what extent do branding processes in the context of urban governance meet norms of democratic legitimacy, and which conditions can account for this? The research goal is explorative. We develop a conceptual framework of norms of legitimacy that can be used in empirical analysis. We then use this framework to examine branding processes in two local communities in the Dutch city of Rotterdam.

This paper aims to relate theoretical insights concerning governance, democracy, and legitimacy to branding. It explores the relationship and tensions between branding and democratic urban governance. We specifically consider two issues: (1) the democratic legitimacy of the branding process itself to uncover the democratic legitimacy of influencing symbolic identities of places through branding; (2) how branding is embedded in urban governance. Does branding amount to more than simply developing images, but rather also represent a means through which citizens gain or lose influence on the planning of the city's future?

The paper is structured as follows. The second section introduces our theoretical framework, clarifying the concepts of branding and democratic legitimacy, and subsequently indicating the most important tensions between these two concepts. The third section presents our research design. We then present the two Rotterdam cases. We close by presenting a number of conclusions. 


\section{Theoretical Framework}

\section{Branding as a form of perception management}

Brands are symbolic constructs meant to add value or meaning to something. A brand is not the product itself; it is what gives meaning and value to the product and defines its identity (Kapferer, 1992). Brands are signs that identify objects and their producers, and also evoke associations that imbue objects with cultural meaning. For example, the Paris brand may evoke such associations as 'romance' and 'light.' The particular symbolic meaning added by the brand also helps to differentiate products from their competitors. Place branding involves influencing people's ideas by forging particular emotional and psychological associations with a place.

Branding is a strategy for managing perceptions (Eshuis and Klijn, 2012). Branding differs from rational and deliberative approaches to influencing perceptions. Rational approaches aim to convince actors through scientifically established information and planned extension. Deliberative approaches aim to facilitate deliberation between actors to develop new frames and jointly accepted packages of solutions, for example through reframing (Schön and Rein, 1994).

Branding on the other hand emphasises the emotional and the psychological; it is not particularly aimed at either deliberation or reason. Branding is not characterised by the systematic processing of information and rational weighing of arguments, but rather by affective and quick assessments based on heuristics. For example, the city of Manchester was not branded primarily by providing fact sheets comparing it with other cities; the branding involved evoking an image and associating the city with such emotional, impressionistic adjectives as 'exciting,' 'lively,' and 'cosmopolitan'(Young et al., 2006). Second, branding works partly through the unconscious. People are largely unaware of the associations triggered by brands, and they do not commonly deliberate about them. As we discuss in the section on legitimacy, the aspect of people's unawareness regarding the associations that brands trigger evokes questions about legitimacy. Before that, we consider the involvement of citizens in branding processes in the next section.

\section{Branding as top-down persuasion or inquiry about citizens' needs}

When authorities develop place brands, they can involve citizens to varying degrees, depending on the branding approach they choose. The marketing literature distinguishes two main branding approaches: a sales-oriented approach and a marketing-oriented approach (Lees-Marshment, 2004). We see these approaches as two ends of a continuum, with little citizen influence at one end (sales approach) and high citizen influence on the formulation of the brand at the other end (marketing approach).

The sales-oriented approach aims primarily at persuading citizens and selling products. The focus is on communicating the quality and performance of branded products (e.g. investment opportunities in a city). Branding is used to add symbolic and emotional qualities to the place, as in the case of Hong Kong, which brands itself as a world-class city and stresses opportunities for global business. Branding is applied to impose particular meanings and 
transmit messages from the top down. Whether top-down branding is manipulative depends on such factors as the benevolence of the authorities and the openness of the intentions of branding campaigns.

At the other end of the continuum, the marketing approach centres on getting to know the needs of citizens and then creating brands that respond to those needs. Branding is no longer viewed primarily as selling, but as satisfying citizens' needs (cf. Lees-Marshment, 2004; Kotler et al., 1999). The idea is that branding is more effective if it is targeted at what people want, and an important aim is therefore to understand the concerns and wishes of citizens and then design a brand that reflects these (Lees-Marshment, 2004). In this context, branding involves not only the transmission of messages but also their reception, and it involves developing brands that respond to people's demands. Branding is about responsiveness rather than persuasion. As we elaborate later in this paper, the aspect of responsiveness contributes to democratic legitimacy in this approach to branding. The marketing approach is oriented towards creating symbolic brands, although it may also go a step further to include adapting the products to consumer wishes. Translated to urban governance, a marketing-oriented approach can involve the creation of a symbolic place brand that fits the demands of citizens, but it can also be intertwined with wider urban policies that are adjusted to citizens' demands. Thus citizens' influence on brands may also effectuate change in wider policies.

\section{Branding in the context of neo-liberal policies}

As mentioned in the introduction, place branding can be seen as part of the entrepreneurial city and the neo-liberalisation of urban governance. In terms of democratic legitimacy, neoliberal governance has been criticised for creating a democratic gap by moving power away from democratically chosen governmental bodies, towards undemocratic corporate organisations (Brenner and Theodore, 2002).

Scholars using the concept of governmentality have argued that citizen participation in a neoliberal context is a governmental 'technology' to realise governmental policies, rather than a transfer of power to citizens. Governments establish the rules in participatory arrangements, shaping citizens' behaviour. Participation is a means of controlling citizens at a distance (Rose and Miller, 1992). From this viewpoint, citizen participation in branding processes can be understood as a technology of government that enrols citizens in neo-liberal policy programmes.

We, however, argue that branding and other urban policies in neo-liberal contexts cannot be understood so straightforwardly. Neo-liberalism may be important as the political backdrop to urban governance, but urban policies have "their own distinct political dynamics and rationale" (Marinetto, 2003, p. 108). The power structures and political mechanisms that underlie neo-liberal urban governance are influenced and modified by policy programmes with other origins, such as national social and educational policies, as well as by democratic cultures that may favour citizen empowerment. Neo-liberal urban governance should not be taken as encompassing and deterministic. Studies taking a governmentality perspective may underestimate actors' agency (Lever, 2011; Larner, 2000). Citizens are not victims of neo- 
liberalism, but rather conscious subjects with certain room for manoeuvre within a neo-liberal context. They may temper or sometimes even modify neo-liberal policy programmes in accordance with local needs.

Under the influence of diverse power structures, urban policies, and the agency of local actors, neo-liberalisation may take different forms in different times and spaces (Larner, 2000; Brenner and Theodore, 2002). We view urban governance in neo-liberal contexts as a contingent, complex, and messy process (cf. Larner, 2000). It begs detailed analyses of cases to understand how the democratic legitimacy of neo-liberal governance and branding work out in specific localities (cf. Larner, 2000; Brenner and Theodore, 2002).

Taking the literature on governmentality and neo-liberalisation into account, we critically analyse our cases and investigate whether the agenda is genuinely open, who determines the rules of participation processes, and whether the outcomes are in line with what citizens want.

\section{Democratic legitimacy}

Questions regarding how political communities allocate scarce resources to achieve their collective goals are always controversial. The concept of democratic legitimacy concerns the grounds upon which the members of a democratic association accept the decisions that are made and the outcomes that are produced. Legitimacy involves the conversion of power into authority, thereby establishing "simultaneously an obligation to obey and a right to rule" (Schmitter, 2001, p. 3).

Max Weber defined legitimacy in terms of the belief in legitimacy by social agents (Weber, 1922/1968). Several social scientists (e.g. Schaar, 1969) have criticised Weber's approach as it seems to imply the abandonment of any normative evaluation of political regimes. Indeed, legitimacy "requires more than the consent of the governed" (Connelly, 2010, p. 4), and not every political regime that engenders a belief in its legitimacy would count as legitimate. As Beetham (1991) argues, these are plausible criticisms in an age of propaganda and public relations, but they should not imply "that the social scientist ought to become a moral or political philosopher, and engage in evaluating a regime against independent normative standards" (Beetham, 1991, p. 10; our italics). Both approaches can be avoided if we consider people's beliefs in conjunction with the normative grounds for these beliefs.

Following this line of reasoning, a conceptualisation of democratic legitimacy can focus on justifiability. Normative concepts of legitimacy in the contemporary literature are often expressed in terms of "justifiability among political equals, for instance by appeals to hypothetical acceptance or consent, [...] under appropriate choice conditions" (Føllesdal, 2006, p. 447). These choice conditions may refer to constitutionally guaranteed basic rights such as free speech and freedom of information. We take the concept of democratic legitimacy to focus on democracy as an overriding "legitimation principle," which is "a procedure that sets the terms for reaching legitimate decisions" (Eriksen and Fossum, 2004, p. 445). 
Legitimacy may refer to different objects. In the concept of legitimacy described above, legitimacy refers to the justifiability of a power relationship, a political system or regime, although it may also concern particular political decisions, public institutions, or political actors (Føllesdal, 2006, p. 450). If we link the concept of democratic legitimacy to branding in the context of urban governance, we focus on the question of how the process of place branding influences the legitimacy of urban governance, of which branding is a part.

Up to this point, we have discussed democratic legitimacy as a general notion about how authority is recognised as valid or justified. The next step is to decompose the concept by distinguishing input, throughput, and output as relevant dimensions, in line with political systems theory (Easton, 1965). Scharpf (1997) introduced political system concepts in the context of legitimacy. He argues that "democratic procedures are essential in input-oriented arguments, whereas they have only instrumental value in the context of output-oriented arguments" (Scharpf, 1997, p. 153). Output-oriented arguments confer legitimacy on decisions that effectively solve problems requiring collective solutions and serve the common good. Risse and Kleine (2007) propose the notion of throughput legitimacy for the quality of the decision-making process itself, which includes criteria of legality of the decision-making process, its transparency, and its deliberative quality.

In our evaluative framework, we follow these political system dimensions. Input legitimacy relates to the openness of decision-making processes. Relevant norms include the openness of the agenda-setting process, opportunities for citizen participation, and the responsiveness of representation by elected politicians, interest groups, or other political representatives to the demands and interests of citizens. The process of branding an urban community can claim democratic legitimacy if the process is open to the participation and inputs of present and future residents, entrepreneurs, and other users of the community. If citizen involvement is indirect, it is important to assess whether representatives are actually acting in the interests of their constituency.

We define throughput legitimacy in terms of the quality of the processes and procedures through which binding decisions are made. Relevant norms include legality, the quality of participation and deliberation, the existence of checks and balances, and the transparency of the decision-making process. In a democratic polity, legality should be guaranteed by the rule of law (Risse and Kleine, 2007). According to the participative model of democracy, legitimacy depends on identity and interest-based citizen participation. The quality of participation involves incorporating the diversity of identities, perspectives, and interests within a community into a branding process with a view to collective learning and forming a shared sense of identity. The deliberative model of democracy also provides measuring tools for evaluating the quality of participation (Eriksen and Fossum, 2004, p. 445). It is also important to consider the interests of minority groups or weakly organised interests. Checks and balances in the participatory process should ensure that these groups are not pushed aside by majorities or powerful stakeholders. 
The output-oriented dimension of legitimacy concerns the capacity of a political system to produce certain outputs or outcomes that actually contribute to the remediation of collective problems. Relevant norms include the effectiveness and efficiency of the decision-making process and the policies that result from it. We add responsiveness to this pair of norms, thus relating "performance" to the needs and values of citizens (Lord and Beetham, 2001, p. 444). The branding process should reflect a common belief in the capacity of the political system to remedy collective problems.

An important aspect of democratic legitimacy involves the organisation of accountability. In the literature, accountability is subsumed in different ways. Risse and Kleine (2007) include accountability in input legitimacy. Wolf (2006) subsumes it under throughput legitimacy, whereas Scharpf (1997) relates it to both input and output legitimacy. In this paper, we focus on accountability as a norm of output legitimacy, meaning the evaluation of the results of collective decision making and its explanation to citizens.

\section{Analytical framework}

To analyse our data in a systematic way that fits our theoretical framework, we developed the analytical framework depicted in Table 1 . The fourth column represents the indicators used to analyse the cases.

\section{INSERT TABLE 1 HERE}

\section{Branding and the democratic legitimacy of urban governance: Opportunities and tensions}

Place branding, as mentioned in the introduction, has been criticised as lacking democratic legitimacy. However, as indicated in the section about branding as an inquiry about citizens' needs, marketing can potentially be used to include citizens in brand construction. Place branding does not necessarily contradict norms of democratic legitimacy. With regard to input legitimacy, branding offers opportunities for legitimacy, as in cases of neighbourhoodrestructuring processes, in which symbols and images are created in open communication with the community. In contrast, if brands are treated as simply attractive labels for neighbourhood designs created in closed and top-down policy processes, tensions can arise between democratic legitimacy and branding.

With regard to throughput legitimacy, a rich approach to branding that combines integrative and aggregative devices can facilitate a process through which citizens can express their sense of identity, feelings of attachment, and aspirations. In contrast, tension can arise between a narrow managerial approach to branding and the norm of quality in participation. Further tension can develop if branding draws upon the more affluent social groups and stakeholders, thereby pushing minority groups or weakly organised interests aside.

If brands refer to solutions that are responsive to the problem definitions and needs of citizens, branding strengthens the output legitimacy of urban governance. In contrast, tension 
between branding and output legitimacy arises if branding functions merely as a rhetorical device that obscures an actual neglect of collective problems as experienced among the residents and other users of a place. Furthermore, branding is in conflict with accountability if there are no mechanisms for monitoring the realisation of the promises communicated by a brand and for holding the responsible actors accountable.

\section{Research Design}

\section{Research strategy}

We use theoretical sampling (Eisenhardt, 1989) to analyse two contrasting cases of city redevelopment. Both cases involve a community in Rotterdam. As we outline in the next section, the city faces several problems and challenges that the city government is attempting to address through policies of revitalisation and restructuring. By looking at two cases of neighbourhood redevelopment in one city, we are following a 'most similar systems' design (Przeworski and Teune, 1970). The two neighbourhoods share a number of characteristics relating to their location in Rotterdam, as well as the same administrative conditions. These characteristics and conditions can be treated as 'controlled for,' thereby enabling us to focus on a limited number of non-shared characteristics of the branding process. If we find significant differences in the legitimacy of the branding processes, this will warrant an explanation in terms of the non-shared characteristics. This research strategy serves the exploratory aims of this paper; but the efficacy of this strategy in providing knowledge that can be generalised across cities is limited, certainly outside the Netherlands.

The cases involve the communities Katendrecht and New-Crooswijk. Both neighbourhoods have governance programmes involving restructuring and revitalisation, rooted in mixedhousing policies. For both neighbourhoods, this involves creating more housing for the middle and upper classes, with the aim of boosting the local economy and lowering the concentration of problems related to socio-economic disadvantage. Katendrecht and NewCrooswijk are contrasting cases in terms of two aspects of our research: (1) the embedding of the branding process in the restructuring process; (2) citizen involvement in the restructuring process. Embedding determines whether citizen involvement in the branding process involves merely symbolic influence over the brand or whether it also influences wider urban governance. In Katendrecht, a residents' association was involved in the restructuring process. The branding process was an integral part of the revitalisation of the neighbourhood. In NewCrooswijk, a group of citizens was involved in exploratory phases of the restructuring, but not in the actual design of the plan. The redevelopers started their branding campaign after the city council adopted the plan and citizens' resistance had been broken.

\section{Research methods}

Data for both case studies were collected through a combination of interviews, observations, and document analyses. We conducted six semi-structured interviews in Katendrecht. In New Crooswijk, which was a more contested process involving more actors, we conducted seventeen interviews. For each case, we organised a discussion session with public officials. 
Developments in both communities were observed during several visits. In addition, we analysed secondary material, including websites, marketing material and policy documents.

\section{Empirical Findings}

\section{Background}

Rotterdam faces several serious problems. The average income is lower than in other Dutch cities, and the level of education is below average. Rotterdam also faces a relatively high level of unemployment. Behind these indicators lies a process whereby white-collar professionals and managers with advanced education are leaving Rotterdam rather than remaining in the city (City of Rotterdam, 2003). A frequently cited reason for this flight is a lack of housing suitable for the middle and upper classes. The city is therefore striving to create housing for the professional and managerial classes (City of Rotterdam, 2003, 2006).

An interesting aspect of our case selection in a national and international context concerns citizen participation. Traditionally, the Dutch political system is geared to a consensual type of policymaking, including forms of participatory democracy (Hendriks and Michels, 2011). In recent decades, numerous Dutch cities have experimented with 'interactive governance' which involves citizens in planning processes at an early stage. Rotterdam represents a special case because it combines a top-down model of urban restructuring policies - which have strong social-democratic political origins - with forms of 'street democracy' in which residents are facilitated to improve their immediate local environment. Such participatory practices may give community leaders and public managers some counter-steering power in various contexts of urban governance (e.g. Van Hulst et al., 2011).

\section{Branding the community of Katendrecht}

Katendrecht is a peninsula largely surrounded by water. At the end of the nineteenth century, Katendrecht was a harbour zone, with many dockworkers living in the community. In the 1960s, the harbour moved westwards, and many companies left Katendrecht. The community began to decline. The level of facilities decreased, houses and other buildings deteriorated, and criminality became clearly visible. The community developed a bad image. Currently, a revitalisation programme is being implemented that includes the conservation of the old centre and the construction of 1,600 new residences. The parties involved want to preserve the centre and the identity of the community.

In order to attract new residents, several parties (i.e. the city council, district council, developers, housing corporations, and the residents' association) have developed a new brand for the community. The ideas for a formal branding campaign started to crystallise in 2004. All parties agreed that a clear positioning of Katendrecht was essential for the restructuring, particularly with regard to the successful sale of the apartments that were to be built. This was the basis for a communication strategy, including a branding campaign. One essential feature was that the residents had become tired of empty promises and unimplemented plans. As a public official explains, the communication strategy therefore was: "residents first, don't 
make it more beautiful than it is, and especially, if you have communicated something, you need to make it come true soon thereafter."

Compared to other communities in Rotterdam, the citizens of Katendrecht are relatively well organised and influential. Public officials sometimes refer to the chair of the residents' association as the Mayor of Katendrecht. On the basis of his detailed knowledge about policy processes and their history, he is a discussion partner for public officials, and because of his good contacts in the neighbourhood he can generate support or protest among residents.

Formally, the residents' association has an advisory function in the restructuring. In practice, it is difficult to implement plans if the residents' association strongly opposes them. Because of this relatively strong position of the residents' association, they were regularly consulted and informed. Thus it was also logical to involve them in the branding process that was seen as part of the overall restructuring process.

We first address the indicators of input legitimacy. There were opportunities for residents to participate directly and indirectly in the development of the branding campaign. Indirect participation took place through the residents' association that had a say in the development of the branding campaign. They made clear that they did not want a campaign that would sketch rosy pictures with exaggerated marketing jargon, in which the identity of the community was not taken seriously. The residents' association told the professionals who were setting up the branding campaign that the residents considered themselves ordinary people, so they wanted an ordinary campaign. Further, they demanded that the existing identity of the neighbourhood be taken into account. This input was used to develop a campaign with which the residents could identify (see picture 1 in Figure 1 for an example of an image used in the campaign). Hence, the branding campaign's agenda was open to citizens' demands on a point that was crucial to the residents' association. The input of the residents' association incorporated existing feelings of identity and rational demands regarding the restructuring within the community (responsiveness of representation). Nevertheless, although the residents' association has a wide support base in the community, the extent to which they represented the viewpoints of the entire community is uncertain.

Citizen participation did not take place solely through the residents' association. There was also direct participation, although this was limited. An interactive session was held to determine the brand values that would underlie the campaign. The invitation policy for this interactive session, however, was closed and selective. About twenty people, including about ten professionals working in the area and about ten residents, participated in the session. By involving professionals and citizens, the actors attempted to include diverse interests and identities. However, the selective resident participation indicates a limited representation of the very diverse range of community identities and interests.

We proceed with the indicators of throughput legitimacy. According to the interviewees, the residents' association was informed regularly during the development of the branding campaign (transparency). However, few residents outside the residents' association were informed. Checks and balances in the decision-making process were informal but present. 
Although the residents' association had little formal power, it proved relatively influential in informal terms. The municipal project leader insisted on involving the residents' association. According to the residents' association, "he told the marketing bureau: 'you are going to create the campaign but you will discuss it with KBO' [the residents' association]." Several discussions were held and some adjustments were made to the campaign. The deliberative quality of the process was such that the residents' association, and also the housing association, the municipality, and the developer, were able to express their standpoints in argumentative discussions.

The interactive session contained creative elements in which participants assembled their perceptions of Katendrecht by cutting and pasting pictures. The session also provided opportunities to enter discussions, in which participants reached consensus about the main brand values for Katendrecht: 'island and distinctiveness' (in combination) and 'contrasts.'

In terms of output legitimacy, the branding campaign was responsive to the wishes of the people to present a realistic picture of the community. A marketing bureau translated the brand values that came out of the interactive session into a brand with a logo, images, and a slogan. Using the motto Can You Handle the Cape? (see www.kunjijdekaapaan.nl), a campaign was developed that does justice to the character of Katendrecht and indirectly refers to the perceived dangerous character of Katendrecht, while adding the twist of adventure. The campaign is full of symbolism referring to seafaring, water, and adventure. It presents Katendrecht as a unique place with special, slightly eccentric, and strong-willed residents (see Figure 1). Altogether, the brand reflects a key concern of residents and policymakers, namely preserving the identity of the existing community. The brand was the symbol capturing that idea.

Other elements of output legitimacy are more difficult to determine because the effects of the branding campaign are difficult to establish. The campaign's contribution to the success of Katendrecht's revitalisation is unclear. However, the brand did reflect the wish to preserve the identity of the community throughout the restructuring process, and the brand informed actors about the neighbourhood identity throughout the process. Accountability was low, because there was no specific process for rendering account about the branding campaign and its results.

The brand was embedded in the restructuring process, because branding was considered necessary to improve the image of the new, restructured neighbourhood. The brand was interlinked with the restructuring process, as it became one of the resources for informing the actors in this process about the neighbourhood's identity. The actors are trying to avoid developments that break with the brand. For example, current policy selectively allows shops and companies to operate in the community, depending on whether they fit the brand. Although neither the slogan nor the symbols of the brand appear in the spatial plans, the brand identity is recognisable in them. Thus, citizen participation in brand development also informed wider restructuring processes indirectly. Democratic participation in brand development would have been less relevant if the branding had not related to the overall restructuring. In this regard, we note that, overall, residents tend to support the restructuring 
because the huge investments improve both houses and public space. There were disputes about the exact planning of particular streets and buildings, but it is crucial that the restructuring restored the old centre, not demolished it.

This case shows how citizens were involved in the development of a community brand. There were opportunities for citizen participation, and the content of the branding campaign was open to discussion. The branding campaign was responsive to the wishes of the people to present a realistic picture of the community, representing its current identity.

\section{INSERT FIGURE 1 HERE}

\section{Branding the community of New Crooswijk}

New Crooswijk, a community close to the centre of Rotterdam, has been restructured drastically. Since 1997, multiple plans have been developed to decrease the percentage of social housing and build more houses for private ownership by the middle and upper-middle classes. In addition to the goal of solving physical problems in the housing stock, another goal was to address problems in the community through a mixed-housing policy and bringing in more middle-class residents. This is consistent with the overall Rotterdam policy of improving the city's capacity to retain middle and upper-class residents. In the first years of the planning process, citizens were invited to participate in the development of visions for the future community. A crucial moment in the planning process was the establishment of the OCNC (Development Partnership New Crooswijk), a private partnership. In 2004, the OCNC developed a Master Plan, which involved radical restructuring through the demolition of about 1,800 of the 2,100 houses in the community. Residents did not anticipate this plan. The OCNC primarily informed citizens about the Master Plan rather than engaging them in coproduction. Citizen involvement was restricted to working out details of the plan (ANONYMISED, 2010). The Master Plan was severely contested, particularly the demolition of the 1,800 houses. The protesting residents argued that the plans destroyed the original identity of New Crooswijk. In one of our interviews, the city alderman acknowledged this: "In the city council it was observed repeatedly that something had happened which had given rise to a feeling among the residents that this [the 2004 Master Plan] was not 'their plan' anymore." These objections notwithstanding, the city council accepted the plans by a large majority, including the demolition.

For a long time, there was no formal branding campaign. The restructuring process had become highly politicised and sensitive. Managers within the OCNC felt that a branding campaign could cause new resistance. The highest ranks of the organisations involved in the OCNC, however, were communicating the plans and deliberately positioning the future community. The OCNC managers characterised the existing community as having serious social problems and a poor housing stock. They also stressed that New Crooswijk was close to the city centre and a pleasant wooded park. They argued that their plans would lead to a beautiful and attractive community. They positioned the protest as a protest by a small group. 
A group of citizens protesting against the plans typified the planned community as a capitalist project at the expense of many residents who would not be able to afford the new houses (see also: BAVO, 2007). The group tried to block the plans developed by the OCNC. However, the city council accepted the plans.

After the city council took the important decision to proceed with the project, the OCNC had a brand developed; the OCNC financed and coordinated a branding campaign featuring a new logo and slogan (see Figure 2 picture 2). The slogan refers to the good things from the past and contains elements of nostalgia, saying: "A bit of the old days in the present." The logo shows a green tree, constructing the future community as pleasant, lush, and green.

A close look at the indicators of input legitimacy shows that there were no opportunities for citizens to participate in the development of the brand. The OCNC, which felt that it was their campaign, commissioned a marketing bureau to carry out the campaign, and citizens were informed about the brand only after it had been developed. There was limited openness to the demands of residents; however, attempts were made to include New Crooswijk residents' sentiments that emphasised the architectural and social qualities of the community that should be preserved. A communication expert from OCNC indicated that the campaign "contains a sort of goodwill to the current residents. So dear people we are going to execute works in your community, but after that you will still recognise it." Overall, the input legitimacy of the branding process in New Crooswijk was very weak. Residents were not involved in this campaign, although notions relating to the historical identity and diversity of New Crooswijk, which were the core of the vision that the residents had in mind, were instrumentally used in the branding of the new neighbourhood. The branding campaign was conceived as an instrument to facilitate the selling of the new houses.

The throughput legitimacy was also weak. The legality of the process is beyond doubt, but the quality of the process of participation and deliberation was low. There were no opportunities for citizens to enter discussions about the brand. As the branding process was designed according to a top-down approach, in which the OCNC was the dominant actor, checks and balances were virtually absent. Furthermore, citizens had no insight into the development of the branding campaign.

The evaluation of the output legitimacy of the process depends on the level at which one defines the relevant outputs. The result of the branding campaign at a symbolic level - the symbolic brand - was mainly aimed at potential homebuyers from outside the community. As the OCNC communication expert explained about the second campaigning phase: "the idea about the communications is to attune a bit more to lifestyle and the potential new target group." However, the brand did take into account several notions regarding the neighbourhood's historical identity that residents found important. In terms of policies, the output of the branding process was more limited. The brand had little influence on wider processes of urban governance (restructuring), as it was created only after the plans for the neighbourhood had been finalised. Finally, accountability was low. There was no organised 
process for rendering account of the branding process and its results to residents or their (political) representatives.

We also researched how the brand was embedded in wider revitalisation policies for the neighbourhood. We found that the restructuring policies informed the branding campaign, but not the other way round. The goal of building houses for the middle and upper classes was incorporated in the brand identity, but the brand was not used as a symbol to direct the restructuring process.

\section{Conclusions and Discussion}

In our cases, the full potential of city branding to be a process in which citizens and other stakeholders obtain a say about the identity of their communities has not been realised. In New Crooswijk, citizens were excluded from participation in the development of the brand. In Katendrecht, there was a degree of citizen participation, allowing at least some room for the feelings and emotions of residents. An important reason for the difference between the cases is the historically strong position of the residents' association in Katendrecht. Moreover, the restructuring of New Crooswijk was led by a private partnership, whereas in Katendrecht (semi-) public parties had more influence. The private partnership was less oriented towards giving citizens influence than public parties often are. Furthermore, it used its influential position to lobby politicians to stick to their earlier decision to restructure (including demolition) and to neglect on-going protest from part of the residents. This limited the responsiveness of politicians towards protesting local citizens.

The cases show how branding can differ in terms of democratic legitimacy, especially input legitimacy. In Katendrecht, the input legitimacy of the branding campaign was higher than in New Crooswijk. The Katendrecht residents' association was involved in the development of the campaign, and there was limited direct citizen participation through one interactive session with selected residents. In terms of governmentality, the municipality, developer, and housing association determined the rules for direct citizen participation, thus in a way controlling citizens at a distance. However, indirect participation by the residents' association also took place in unsolicited and uncontrolled ways. In New Crooswijk, the brand was developed by a private partnership in a top-down manner. In Katendrecht, emotions of residents played a role in the brand values. Another difference between the cases is the extent to which the branding campaign influenced restructuring policies. In New Crooswijk, the branding campaign did not feed into the restructuring policies as the brand was developed only after the policies had been developed. In Katendrecht, the brand was developed earlier in the policy-development process, and it became a source that informed the restructuring process about the neighbourhood's identity. The feelings and ideas of citizens included in the branding process could feed into the broader restructuring process because the branding process was not organised after the restructuring process, but simultaneously.

In addition, the cases show how governance strategies - such as branding - with neo-liberal origins are applied and acted upon by local actors. In Katendrecht, the residents' association 
claimed that the brand should be responsive to citizens and reflect the existing identity of the community. The branding campaign became a resource in their strategy to conserve the identity of the community in the face of the restructuring programme. The branding process was not purely an avenue of neo-liberalism imposed by the state and private parties, but also a space for discussion in which the residents' association brought in their vision on the restructuring process. In New Crooswijk, the private partnership appropriated and used the brand to further its marketing strategy, without consulting citizens. Here, branding supported a broader neo-liberal agenda of restructuring a community by a public-private partnership.

We cannot draw conclusions from these two cases that are statistically valid to the entire universe of branding and urban governance, but they do allow for theoretical generalisation (Yin, 1984). From them, we draw four theoretical propositions about conditions that enhance the democratic legitimacy of branding in urban governance. The first condition, affecting input legitimacy, involves citizens already having a strong position in the broader governance process (the planning of the restructuring process in our cases). If citizens have influence on the wider governance process, it becomes more difficult to deny them participation in the branding process, as the Katendrecht case exemplifies. The second condition affects input legitimacy as well: citizens should be seen as co-owners of the brand. In one of our cases (New Crooswijk), a private partnership saw itself as the exclusive owner of the brand. It therefore did not consider it necessary to give influence to citizens. The third condition, affecting particularly input and throughput legitimacy, is that citizens see themselves as potential co-owners of the brand and feel the commitment to the brand that comes with the notion of ownership. Without citizens' commitment, it will be difficult to develop dialogues with them about the brand. The fourth condition enhances output legitimacy. The branding process has to be intertwined with wider policies and plans for the community, so that the output of the branding process is not limited to the symbolic representation of the community, but also feeds into the planning processes that influence community development. So, a crucial condition is to start the branding process in an early phase of policy development.

We conclude that branding can theoretically enhance the functioning of urban democracy if it is embedded in a participatory process through which citizens' emotions, feelings, and stylistic preferences are included in both the brand and concrete urban policies, and if citizens are seen as co-owners of the brand. In our cases, this theoretical potential was realised only to a limited degree. The New Crooswijk case does not meet the conditions for a democratic, legitimate branding process, whereas the Katendrecht case meets the conditions in part. Improving the representation of citizens in the branding process, as well as embedding the branding process in the wider urban governance processes, would add to the democratic legitimacy of place branding processes.

\section{References}

Arvidsson, A. (2006) Brands: Meaning and Value in Media Culture. London: Routledge. 
BAVO (2007) Democracy \& the neoliberal city: the Dutch case, in BAVO (Ed.) Urban Politics Now. Re-Imagining Democracy in the Neoliberal City. Rotterdam: NAI Publishers.

Beetham, D. (1991) The Legitimation of Power. London: Macmillan.

Bennett, R. and Savani, S. 2003. The rebranding of city places: an international comparative investigation, International Public Management Review 4(2), pp. 70-87.

Brenner, N. and Theodore, N. (Eds). 2002 Spaces of Neo-liberalism: Urban Restructuring in North America and Western Europe. Malden: Blackwell.

Brownill, S. (1994) Selling the inner city: regeneration and place marketing in London's Docklands, in: J.R. Gold and S.V. Ward (Eds) Place Promotion: The Use of Publicity and Marketing to Sell Towns and Regions, pp. 133-151. Chicester: Wiley.

City of Rotterdam (2003) Wonen in Rotterdam. Aanpak tot 2006. Koers tot 2017 [Housing in Rotterdam. Approach to 2006. Course to 2017].

City of Rotterdam (2006) Collegeprogramma 2006-2010 [Coalition policy programme 20062010].

Connelly, S. (2010) Constructing legitimacy in the new community governance, Urban Studies, 47, pp. 1-18.

Easton, D. (1965) A Systems Analysis of Political Life. New York: Wiley.

Eisenhardt, K.M. (1989) Building theories from case study research, The Academy of Management Review, 14, pp. 532-550.

Eriksen, E.O. and Fossum, J.E. (2004) Europe in search of legitimacy: strategies of legitimation assessed, International Political Science Review, 25, pp. 435-459.

Eshuis, Jasper and Erik-Hans Klijn (2012) Branding in Governance and Public Management. London: Routledge.

Føllesdal, A. (2006) Survey article: the legitimacy deficits of the European Union, The Journal of Political Philosophy, 14, pp. 441-468.

Greenberg, M. (2008) Branding New York: How a City in Crisis was Sold to the World. New York: Routledge

Hackworth, J. (2007) The Neoliberal City: Governance, Ideology and Development in American Urbanism. New York: Cornell University Press.

Hall, T. and Hubbard, P. (Ed.) (1998) The Entrepreneurial City. Geographies of Politics, Regime and Representation, pp.1-23. Chichester: Wiley.

Hatch, M. and Rubin, J. (2006) The hermeneutics of branding, Brand Management, 14, pp. 40-59.

Hendriks, F. and Michels, A. (2011) Democracy transformed? Reforms in Britain and The Netherlands (1990-2010), International Journal of Public Administration, 34(5), pp. 307-317.

Jones, P. and Evans, J. (2008) Urban Regeneration in the UK. London: Sage.

Kapferer, J.-N. (1992) Strategic Brand Management: Creating and Sustaining Brand Equity

Long Term. London: Kogan Page.

Kavaratzis, M. (2008) From City Marketing to City Branding. An Interdisciplinary Analysis with Reference to Amsterdam, Budapest and Athens. Published $\mathrm{PhD}$ Thesis. Groningen: Groningen University. 
Kotler, P., Armstrong, G., Saunders, J. and Wong, V. (1999) Principles of Marketing. 2nd European ed. London: Prentice Hall.

Larner, W. (2000) Neo-liberalism: policy, ideology, governmentality, Studies in Political Economy, 63, pp. 5-25.

Lees-Marshment, J. (2004) Mis-marketing the conservatives: the limitations of style over substance, The Political Quarterly, 75, pp. 392-397.

Lever, J. (2011) Urban regeneration partnerships: a figurational critique of governmentality theory, Sociology, 45, pp. 86-101.

Lord, C. and Beetham, D. (2001) Legitimizing the EU: is there a 'postparliamentary basis' for its legitimation?, Journal of Common Market Studies, 39, pp. 443-462.

Marinetto, M. (2003) Who wants to be an active citizen? The politics and practice of community involvement, Sociology, 37, pp. 103-120.

Paddison, R. 1993. City marketing, image reconstruction and urban regeneration, Urban Studies 30(2), pp. 339-350.

Przeworski, A. and Teune, H. (1970) The Logic of Comparative Social Inquiry. New York: Wiley.

Risse, Th. and Kleine, M. (2007) Assessing the legitimacy of the EU's treaty revision methods, Journal of Common Market Studies, 45, pp. 69-80.

Rose, N. and Miller, P. (1992) Political power beyond the state: problematics of government, British Journal of Sociology, 43, pp. 173-205.

Schaar, J.M. (1969) Legitimacy in the modern state, in: P. Green and S. Levinson (Eds) Power and Community: Dissenting Essays in Political Science, pp. 276-327. New York: Vintage.

Scharpf, F.W. (1997) Games Real Actors Play. Boulder, CO: Westview Press.

Schmitter, Ph.C. (2001) What is there to legitimize in the European Union ... and how might this be accomplished?, Political Science Series 75. Vienna: Institute for Advanced Studies.

Schön, D.A. and Rein, M. (1994) Frame Reflection: Toward the Resolution of Intractable Policy Controversies. New York: Basic Books.

Van Dijk, P. and Holstein, A.N. (2007) How to brand a neighbourhood? Innovative citizen participation in urban planning, in: G. Amos and D. Warburton (Eds) Community Engagement in Planning - Exploring the Way Forward. Final Report EU INTERREG IIIB Project.

Van Hulst, M., de Graaf, L. and van den Brink, G. (2011) Exemplary practitioners. A review of actors who make a difference in governing, Administrative Theory and Praxis, 33(1), pp. 120-142.

Weber, M. (1922/1968) Economy and Society. Edited by Guenther Roth and Claus Wittich. New York: Bedminister Press.

Wolf, K.D. (2006) Private actors and the legitimacy of governance beyond the state, in: A. Benz and Y. Papadopoulos (Eds) Governance and Democracy: Comparing National European and International Experiences, pp. 200-227. London: Routledge.

Yin, R.K. (1984) Case Study Research: Design and Methods. Beverly Hills, CA: Sage.

Young, C., Diep, M. and Drabble, S. (2006) Living with difference? The 'cosmopolitan city' and urban reimaging in Manchester, UK, Urban Studies, 43, pp. 1687-1714. 